\title{
The Correlation Between the Use of Instagram and Female Adolescents' Body Image
}

\author{
Widiya Fitria Pharamita ${ }^{1}$ Agoes Dariyo ${ }^{1 *}$ \\ ${ }^{1}$ Faculty of Psychology, Universitas Tarumanagara, West Jakarta 11440, Indonesia \\ "Corresponding author. Email: agoesd@fpsi.untar.ac.id
}

\begin{abstract}
This Covid-19 situation has forced individuals to practice physical distancing and stay at home. This affects individuals' communication with each other. One of the means of communication that can be used for longdistance communication is social media or application. This thesis discusses the correlation between the intensity of Instagram usage and female adolescents' body image. The research methods used were descriptive and quantitative methods, using a correlational technique. The number of respondents who participated in this research is 184 people. The respondents were selected using purposive sampling technique, respondents are females in the age range of 18-22 and located in Jabodetabek area. The technique of data collecting is by using a questionnaire shared through Google Form to the respondents. The next step was to prove and analyze the data, so a variety of tests were performed, including validity test, reliability test, assumption testing that involves normality and linearity tests, and a hypothesis analysis was also conducted. Since this research uses a correlational technique, the assumption testing used are normality and linearity tests. The result of data processing of the normality test shows that the data are not normally distributed, with the result of $0.023<0.05$ and $0.013<0.05$. On the linearity test, the result is $0.386>0.05$, so it can be concluded that the data are linear. In the calculation using Spearman correlation, the result is 0.997 and the score of sig. of $0.000<0.05$, which means both variables in this research have a positive and significant correlation.
\end{abstract}

Keywords: Intensity, Instagram, Social Media, Body Image, Female Adolescents

\section{INTRODUCTION}

Physical appearance in human life is a crucial aspect, humans have frequently taken an interest in this matter. Grogan (2008) [1] has argued that individuals tend to view their physical appearance differently, based on their perceptions, thoughts, and feelings. An individual's perception of the shape and size of their body is called body image. According to Honigam and Castle (as cited in Januar, 2007) [2] after perceiving themselves, an individual tends to make judgment on what they feel and think, this is certainly supported by others' evaluation of them. Since the perception and evaluation are subjective, they may not correspond to the individual's real body. Based on Hardisuryabrata (as cited in Denich \& Ifdil, 2015) [3] subjective perception and evaluation of body image may appear before one observes deeper about the real condition. Regarding that condition, there must be factors that influence someone, especially adolescents, in perceiving their body image.

In perceiving adolescents' bodies, physical factors play an important role, those factors include age, gender, pubertal maturation, and even the composition of the body (Walker
\& Avant, 1995) [4]. Aside from physical factors, there are also sociocultural factors that affect one's perception of seeing their body image. The perception of surrounding society may affect an individual, due to the imagination, emotion, mood, situation of the surroundings, and the personal experience of each individual. According to Muth and Cash (1997) [5] someone's perception of their body image may affect their well-being in a psychological aspect. Muth and Cash has also argued that perception of body image may be measured by satisfaction and dissatisfaction. Having an ideal body is every individual's dream, according to Amalia (2007) [6], the dissonance of one's body condition with what they wish for, will cause body dissatisfaction. Therefore, in a situation like this, there would be a social comparison process between one another. Hence, it can be concluded that the definition of body image is an individual's subjective perception of their body condition. If their body is what they hoped for and wanted, the individual will be satisfied. On the contrary, if it is not what they hoped for and wanted, they will feel dissatisfied, which leads to negative body image.

According to Thompson (2000) [7], there are levels to measure the body image for discovering the individual's satisfaction of their body as a whole, and to discover the 
levels of the acceptance of the external environment of body condition would be by observing the sociocultural aspects. Those aspects are others' reaction to the individual, comparison of the individual with another, the role of the individual in living their life, and others' identification of the individual that helps them to recognize their body image.

As time goes by, technology has advanced, the four sociocultural aspects can be easily obtained from the Internet, one of which is social media. Social media is defined as a form of online media, in which users from all over the world can participate, communicate, share, and create contents in various platforms, such as wiki, blog, forum, social network, and visual world (Wikipedia, 2020) [8]. Oberst, Wegmann, Stodt, Brand, and Chamarro (2017) [9] have argued that social media are internet-based communities created visually to build profiles individually and socially, used for communicating, and social media users has been increasing along with time, and the majority of users are adolescents. Thompson et al. and Van den Berg et al. (as cited in Fardouly, 2017) [10] have argued that body image shown through social media can lead to 2 things, namely, ideal beauty standard, and the possibility of the occurrence of comparing one's appearance to another. In the era of globalization, social media has become crucial and mostly have been used by everyone.

Social media that are currently owned and used by many are YouTube, Instagram, Tik Tok, Facebook, Facebook Messenger, WhatsApp, Twitter, Line, Pinterest, LinkedIn, Snapchat, Skype, and more. As time goes by, technology has been developing, so it has become easier to exchange information, and to communicate with each other. In Hootsuite (We Are Social) research: Indonesian Digital Report regarding countries as long-time users of the Internet, Indonesia is one of the top 10 of the list. As reported by KumparanTECH [11], during 2019, the average time of Internet usage is approximately 7 hours 59 minutes, and it is used to access social media, and the majority of users are 16-64 years old.

We Are Social in 2020 reported that there was an increase of $17 \%$ or approximately 25 million users, so the total of Internet users in Indonesia was 175.4 million people, or 64\%. In 2018, Asosiasi Penyelenggara Jasa Internet Indonesia (APJII) reported the percentage of the age of Internet users in Indonesia, the highest percentage was $49.52 \%$, which was dominated by people in 19-34 age range, $29.55 \%$ of those in $35-54$ age range, $16.68 \%$ of those in $13-18$ age range, and $4.24 \%$ of those who are beyond 54 years old. Most Internet users in Indonesia reported in 2018 are in the age range of 19-34. With social media, people can easily communicate with other users without any limitation in time and space, and it can be done wherever and whenever. The top 3 of social media as explained by Hootsuite (We Are Social): Indonesian Digital Report (as cited in Riyanto, 2019) [12], are Youtube with the percentage of $88 \%$, Facebook $81 \%$, and Instagram $80 \%$.

In this research, the researchers have chosen to focus on Instagram, the reason for this is based on the research conducted by Hamid, Ishak, and Yazam (2015) [13], emotional stability will be affected if one uses Youtube and Instagram frequently. The users of Instagram communicate by using uploaded videos or photos. On Instagram, there are the terms of followers and following. According to Ridgway and Clayton (2016) [14], liking or commenting other users' posts is considered as an interaction on Instagram. In their research, Chua and Chang (2016) [15] has found that the number of likes and followers for adolescents are considered as a standard of appreciation from other users for their physical appearance. Due to the increasing number of Instagram users, now it is used as a platform to advertise and promote.

Users who have many followers are the main target of becoming advertisement media, those users are commonly called Instagram celebrities or celebgrams. The appearance of these celebgrams has become a standard for other users. These celebgrams have a focus in different fields, such as fitness, makeup, culinary, and others. Celebgrams with a field that leans on attractive physical appearance, who show an ideal body figure, and get many likes or positive comments from other users, which create a beauty standard, will potentially raise others' intention to have the body they see in Instagram. This phenomenon affects the body image of other users, who do not have ideal bodies like the contents they see in Instagram.

In previous research regarding the correlation of Instagram usage and body image problems and self-objectivity in American women who are in between 18 and 25 years of age conducted by Fardouly (2018) [16] has stated the result showing that there is a negative effect of Instagram usage on women's attention and belief regarding their appearance. The urgency of this research is the increasing number of social media users, specifically Instagram users, and based on previous research that has stated there is a negative effect. By conducting this research, the researchers aim to prove the validity of the previous research, supported by the surroundings that have problems with body image, particularly caused by using Instagram.

\subsection{Body Image}

Based on a quotation by Grogan (2008) [17], body image is "a person perception, thoughts, and feelings about his body." According to Kozier (2004) [18], body image is one's evaluation on their body condition, based on the size, appearance, and function of their body. The evaluation may happen consciously or unconsciously.

Cash (2002) [19] has described five aspects of body image, namely, Appearance Evaluation, this aspect focuses on measuring the attractiveness of an individual's physical appearance. Appearance Orientation, that is one's effort to fix their appearance so they will always look attractive. Overweight Preoccupation, that is when an individual does attempts to prevent gaining more weight, such as dieting and others. Self-Classified Weight, that is the way an individual evaluates their weight, whether it is classified as overweight or underweight. Body Area Satisfaction focuses 
on measuring how satisfied an individual is with their body area.

In the process of forming an individual's body image, there will be some causes. In previous research conducted by Chase (2001) [20] regarding gender. The following is an age factor, which has been explained by Santrock (as cited in Denich \& Ifdil, 2015) [21] that late adolescents tend to have an unstable emotional condition. Cash and Pruzinsky (2002) [22] have explained that there are three factors that cause the formation of body image, namely, family, interpersonal relationships, and mass media. Based on Thompson (2000) [23], other factors include perception, development, and sociocultural factors.

Cash and Pruzinsky (as cited in Seawell \& Burg, 2005) [24] have described five aspects in measuring body image by using Multidimensional Body Self Relation QuestionnaireAppearance Scale (MBSRQ-AS), in which consists of Appearance Evaluation, this aspect focuses on measuring the attractiveness of an individual's physical appearance as a whole. Appearance Orientation, that is putting one's efforts for their appearance, whether it is in the form of attention or improving the quality of their current appearance. Overweight Preoccupation measures how aware one is with their weight and tends to diet and watch their diet. Self-Classified Weight, that is the way an individual categorizes their weight, with the scale of very underweight to very overweight. Body Area Satisfaction focuses on measuring how satisfied an individual is with their body area.

This research used an instrument adapted from SATAQ-4 (Sociocultural Attitudes Towards Appearance Questionnaire-4), SATAQ-4 consists of 22 items that measures five aspects, including perception evaluation of skinny and muscular body ideal and pressure on appearance from the surroundings, such as friends, family, and media. SATAQ-4 instrument uses the rating scale and discusses body image based on body size, eating disorders, and selfesteem (Schaefer, et al., 2015) [25].

\subsection{Intensity of Instagram Use}

In APA Dictionary of Psychology (2020) [26], intensity is a form of stimulus or sensation with a quantitative value or is considered as the strength of an individual's behavior or emotions. The definition of use in KBBI (2020) [27] is a process, method, act of doing something, and usage. Hence, intensity of use is the level of the strength of an act that is measured by a quantitative value. Level or intensity in this research refers to how frequent the Instagram is used.

Based on Wikipedia (2020) [28], Instagram is one of many applications that is used for sharing photos and videos to other users, along with various features, such as followers, following, like button, comment section, and others. Posted photos and videos are a form of communication on Instagram. With the like and comment features, according to Tyler (2016) [29], the higher the number of likes and comments, the more attractive a post is, considered by other users. Users with a large number of followers, likes, comments, and others are called celebgrams or Instagram celebrities. Posted photos and videos in Instagram commonly set the beauty standard in Indonesia According to Cash and Purzinsky (as cited in Lemberg \& Cohn, 1999) [30], this certainly affects the body image of other users. Del Bario (as cited in Taqwa, 2018) [31] has stated four aspects that form the intensity and discussed social media, including Instagram. Appreciation aspect, that is understanding and appreciating information obtained from activities they like. A form of realization from social media can be depicted in following or imitating the information from social media. The duration aspect includes the period of time an individual does activities they like. Oftentimes, individuals lose track of time whenever they are accessing social media, especially Instagram. The last aspect is frequency, which is defined as a habitual behavior. If correlated to the use of Instagram, it can be described as the behavior of accessing social media over and over.

\section{METHODS}

\subsection{Participants and Procedure}

The participants of this research have to meet the criteria, namely, those who are in between 18 and 22 years old, are classified as late adolescents, female, have a smartphone, have an Instagram account and actively use it, and are domiciled in the Jabodetabek area. The total of participants is 197 people, but there were those who did not meet the research criteria and those who filled the questionnaire more than once, so their data had to be discarded and the final number of participants is 184 people. The description of participants can be seen on Table 1 .

Table 1 Description of Participants

\begin{tabular}{ccc}
\hline Characteristic & Total & Percentage \\
\hline Age & & \\
\hline 18 years old & 7 & $3.8 \%$ \\
19 years old & 15 & $8.1 \%$ \\
20 years old & 43 & $23.4 \%$ \\
21 years old & 99 & $53.8 \%$ \\
22 years old & 20 & $10.9 \%$ \\
\hline Domicile & & \\
\hline Jakarta & 70 & $38.04 \%$ \\
Bogor & 7 & $3.8 \%$ \\
Depok & 3 & $1.63 \%$ \\
Tangerang & 79 & $42.93 \%$ \\
Bekasi & 25 & $13.6 \%$ \\
\hline Occupation & & \\
\hline Unemployed & 8 & $4.35 \%$ \\
High school & 2 & $1.09 \%$ \\
students & 167 & $90.76 \%$ \\
University & 7 & $3.8 \%$ \\
students & & \\
Others & & \\
\hline Religion & & \\
\hline Islam & 110 &
\end{tabular}




\begin{tabular}{ccc}
\hline Christian & 46 & $25 \%$ \\
Catholic & 8 & $4.35 \%$ \\
Buddha & 19 & $10.33 \%$ \\
Hindu & 1 & $0.54 \%$ \\
Konghucu & 0 & $0 \%$ \\
Others & 0 & $0 \%$ \\
\hline
\end{tabular}

\subsection{Research Instrument}

The research equipments are laptop, internet access, informed consent as an agreement with the participation of this research that was included in google form, questionnaire as an instrument that was included in google form, and a smartphone to ease the access to communicate with the participants. Google form was shared as a link through Instagram, Line, and Whatsapp to the researchers' colleagues.

The researchers used 50 participants to test the reliability of the instrument. The result of the reliability test from the questionnaire is $0.712(>0.6)$ for the intensity of Instagram use instrument, $0.672(>0.6)$ for body image instrument 1 (MBSRQ) and 0.744 (>0.6) for body image instrument 2 (SATAQ-4).

On the validity test, the questionnaire had a total of 60 items, but there were 15 invalid items, so the questionnaire was discarded, and the remaining was 45 items. The invalid items were on the first instrument, that is the intensity of Instagram use, on the 3rd item, and the body image instrument 1 (MBSRQ), on items 2, 5, 6, 7, 16, 19, 20, 24, $26,28,29,30,31$, and the third instrument, body image instrument 2 (SATAQ-4), on the 16th item. On the validity test, the researchers used 50 participants to test the validity of the instrument.

\section{FINDINGS AND DISCUSSIONS}

On the normality test, the researchers used One Sample Kolmogorov-Smirnov test that aims to discover whether the data are normally distributed or not. One Sample Kolmogorov-Smirnov Test resulted in the score of sig of $0.023>0.05$ for the intensity of Instagram use variable, and $0.013>0.05$ for body image variable. The condition is if $p$ $>0.05$, the data are normally distributed, and to the contrary, if $\mathrm{p}<0.05$, the data are not normally distributed. The results show that the data are not normally distributed. Below is the descriptive table of the result of normality test:

Table 2 Description of Normality Test

\begin{tabular}{lll}
$\begin{array}{l}\text { Asymp. Sig. (2- } \\
\text { tailed) }\end{array}$ & Standard & Description \\
\hline 0.023 & $>0.05$ & Not normally distributed \\
\hline 0.013 & $>0.05$ & Not normally distributed \\
\hline
\end{tabular}

The second assumption testing, linearity test, aims to discover the linear correlation between both variables. The researchers have found the result of 0.386 ( $>0.05$ ), the correlation of both variables can be considered as linear if $\mathrm{p}$ $>0.05$ and not linear if $p<0.05$. Based on the result, it can be inferred that the data are linear. The description of the result of linearity test is as follows:

Table 3 Description of Linearity Test

\begin{tabular}{ccc}
\hline $\begin{array}{c}\text { Deviation from } \\
\text { Linearity }\end{array}$ & Standard & Description \\
\hline 0.386 & $>0.05$ & Linear \\
\hline
\end{tabular}

Based on the normality test, the results show that the data distribution is not normal. Thus, the researchers used Spearman correlation technique to analyze the hypothesis. Correlation analysis between the intensity of Instagram use and body image resulted in a correlation coefficient ( $r$ ) score of 0.997 and the score of sig. of $0.000<(0.05)$. Based on the result, it can be interpreted that there is a significant correlation between the intensity of Instagram use and female adolescents' body image.

The result of this research shows that there is a strong and significant correlation between the intensity of Instagram use and female adolescents' body image. Previous research by Aristantya and Hilmi (2019) [32], has stated that there is a positive correlation between online social support and the body image of high school students who uses Instagram in the Special Region of Yogyakarta, DKI Jakarta, Bandung, and Surabaya. There is a difference between this research with the previous research, in that this research has a broader age range, which is $18-22$ years old, which are classified as late adolescents according to Santrock (as cited in Megawati, E., 2015) [33]. Moreover, on an area aspect, this research has a larger scope of area, but the distribution of participants in each area was not balanced.

This research has found that most participants are long-term Instagram users (more than 2 years) and tend to access Instagram. Most of them consider the contents on Instagram are more interesting than those of other social media. Responses from the participants about body image inclines positively, thus, even though exposed to contents in Instagram, especially about body image, participants tend to have positive body image.

According to Cash and Pruzinsky (2002) [34], there are three factors affecting an individual's body image, namely, family, interpersonal relationships, and mass media. Therefore, the formation of an individual's body image is measured not only based on their social media use, but there are also other factors that have a chance to give positive support for body image.

Referring to a statement by Thompson (2000) [35], that perception or precision of thought may affect an individual's body image, which includes satisfaction and dissatisfaction of their body. If an individual is satisfied with their body, their body image will be positive, and vice 
versa. The researchers found that most participants were satisfied with their bodies. Based on Buss (as cited in Amalia, 2007) [36] the form of an individual's evaluation on their body, whether in the form of thought or feeling, may reflect their important aspect, and if an individual has positive body image, they have a lower tendency of experiencing anxiety disorders.

\section{CONCLUSIONS}

The result of data processing based on Spearman correlation is 0.997 and the score of sig. of $0.000(<0.05)$, based on the result, it can be concluded that there is a significant correlation between the intensity of the use of Instagram and female adolescents' body image. Therefore, the higher the intensity of the use of Instagram, the higher the female adolescents' body image, and on the contrary, the lower the intensity of the use of Instagram, the lower the female adolescents' body image.

\section{ACKNOWLEDGMENT}

The writers would like to thank all participants who are involved in this research.

\section{REFERENCES}

[1] Grogan, S. (2008). Body Image: Understanding body dissatisfaction in men, women and children (2nd ed.). New York: Routledge.

[2] Januar, V. (2007). Citra tubuh pada remaja putri menikah dan memiliki anak. Jurnal Psikologi, 3(3). Fakultas Psikologi Universitas Gunadarma, Jakarta.

[3] Denich, A. U., and Ifdil. (2015). Konsep body image remaja putri. Jurnal Konseling dan Pendidikan, 3(2). Universitas Negeri Padang, Padang.

[4] Walker, L., and Avant, K. (1995). Strategies for Theory Construction in Nursing ( $3^{\text {rd }}$ ed). AppletonCentury-Crofts, Norwalk.

[5] Muth, J. L., and Cash, T. F. (1997). Body-image attitudes: What difference does gender make? Journal of Applied Social Psychology, 27(16), 1438-1452. https:// doi.org/10.1111/j.1559-1816.1997.tb01607.x

[6] Amalia, L. (2007). Citra tubuh (body image) remaja perempuan. Jurnal Musawa, 5(4).
[7] Thompson, J. K. (2000). Body Image, Eating Disorders, and Obesity. Washington, DC: American Psychological Association.

[8] Wikipedia. (2020, September 5). Media sosial. Retrieved from https://id.wikipedia.org/wiki/Media_ sosial

[9] Oberst, U., Wegmann, E., Stodt, B., Brand, M., and Chamarro, A. (2017). Negative consequences from heavy social networking in adolescents: The mediating role of fear of missing out. Journal of Adolescence, 55, 51-60. doi: 10.1016/j.adolescence.2016.12.008

[10] Fardouly, J. (2018). Instagram use and young women's body image concerns and self-objectification: Testing mediational pathways. New media \& society, 20(4) 1380-1395. https://doi.org/10.1177/ 1461444817694499

[11] KumparanTECH. (2020, September 7). Berapa lama orang Indonesia pakai internet setiap hari? Retrieved from https://kumparan.com/kumparantech/ berapa-lama-orang-indonesia-pakai-internet-setiap-hari$1 \mathrm{sm} 18 \mathrm{OYziOQ/full}$

[12] Riyanto, Andi Dwi. (2019, September 5). Hootsuite (We are Social): Indonesian digital report 2019. Retrieved from https://andi.link/hootsuite-we-are-social indonesian-digital-report-2019/

[13] Hamid, N. A., Ishak, M. S, dan Yazam, S. S. N. M. (2015). Facebook, youtube and instagram: Exploring their effects on undergraduate students' personality traits. Journal of Social Media in Society, 4(2),139-159.

[14] Ridgway, J., dan Clayton, R. (2016). Instagram unfiltered: Exploring associations of body image satisfaction, Instagram \#selfie posting, and negative romantic relationship outcomes. Cyberpsychology, Behavior, and Social Networking, 19(1), 2-7. DOI: 10.1089/cyber.2015.0433

[15] Chua, T. H., and Chang, L. (2016). Follow me and like my beautiful selfies: Singapore teenage girls' engagement in self-presentation and peer comparison on social media. Computer Behavior, 55, 190-197. DOI: 10.1016/j.chb.2015.09.011

[16] Kozier, B. (2004). Fundamental of nursing: concepts, process, and practice ( $7^{\text {th }}$ ed.). New Jersey: Pearson Education Inc. 
[17] Cash, T. F. and Pruzinsky, T. (2002). Body Image: A Handbook of Theory, Research and Clinical. New York: Guilford Publications.

[18] Chase, M. E. (2001). Identity development and body image dissatisfaction in college females. New York: Guilford Publications.

[19] Seawell, A, H and Danorf-Burg, S. (2005). Body image and sexuality in woman with and without systemic lupus erythematosus. Sex Roles, 5(11/12), 865-876.

[20] Schaefer, L. M., et al. (2015). Development and Validation of the Sociocultural Attitudes Towards Appearance Questionnaire-4 (SATAQ-4). Psychological Assessment, 27(1), 54-67.

[21] APA Dictionary of Psychology. (2020, September 28). Intensity. Retrieved from https://dictionary.apa.org/ intensity

[22] Kamus Besar Bahasa Indonesia (KBBI). (2020, September 16). Penggunaan. https://kbbi.web.id/ penggunaan

[23] Wikipedia. (2020, September 12). Instagram. Retrieved from https://id.wikipedia.org/wiki/Instagram

[24] Tyler, S. (2016). Instagram: What makes you post? Pepperdine Journal of Communication Research, 4(1), 30-39.

[25] Lemberg, R., and Cohn, L. (1999). Eating disorders: A reference sourcebook (2nd ed.). Arizona: The Oryx Press.

[26] Taqwa, M. I. (2018). Intensitas Penggunaan Media Sosial Instagram Stories dengan Kesehatan Mental. Skripsi. Fakultas Psikologi Universitas Muhammadiyah Malang. Malang.

[27] Aristantya, E. K., and Helmi, A. F. (2019). Citra tubuh pada remaja pengguna instagram. Gadjah Mada Journal of Psychology, 5(2), 114-128. DOI: 10.22146/gamajop.50624

[28] Megawati, E. (2015). Hubungan Antara Perilaku Prososial dengan Psychological Well-Being Pada Remaja. Skripsi. Program Studi Psikologi Fakultas Kedokteran Universitas Udayana. Denpasar. 